\title{
Election of President and Honorary Officers
}

\section{Introduction}

During 1990, elections were held for the President and for the Dean. It is now unusual for the President to be elected after one ballot and therefore the ballot for Officers, which takes place after the election of the President, no longer takes place in April but in May. Last year a second Presidential ballot was held and Professor Sims was notified in May that he had been elected President and would take office two months later in July. The new Dean had less notice than this, only a matter of days between the announcement of the result of the election for Dean and the Annual General Meeting when Dr Caldicott took office. If there had been a second ballot, the College would not have had a Dean until August. It is obviously difficult for Honorary Officers to take on their onerous duties with such short notice. Council has agreed that the timing of elections should change this year to prevent this situation occurring again.

\section{New election procedure}

The Bye-Laws of the College state that the "President shall assume Office at such stage of the Annual General Meeting following upon his election". Council, in future, will receive nominations for the Presidency at its June meeting, rather than its January meeting as at present. This will mean that nominations will be received from the Membership by mid-July. The election will then be held immediately, with a longer period than usual within which to return ballot papers, to take account of the holiday period. Ballot papers will therefore be returned to the College by the beginning of September.

If a second ballot is necessary, this will be completed by mid-October. The announcements of the new President for the following year will be made at the October meeting of Council when nominations will then be received for Honorary Officers. The election for Honorary Officers will then take place during the autumn and early winter months and the results will be announced at the January meeting of Council. The President-Elect will then have nine months to prepare for the Presidency and new Honorary Officers will have approximately six months.

\section{Election of President and Honorary Officers to take up duties in July 1993}

The nominating meeting of Council for the new President will take place on 19 June 1992. An election notice will appear in the June Bulletin, and nominations for the President will be received from the membership until 17 July 1992 . The ballot, or ballots, will take place during August and September and the name of the new President will be announced to Council on 16 October. The procedure will then commence in a similar fashion for the election of Honorary Officers. The President, Registrar, Editor, and Treasurer will all be retiring in 1993.

VANESSA CAMERON

The Secretary

\section{Election of President}

\section{Notice to Fellows and Members}

Fellows and Members are reminded of their rights under the Bye-laws and Regulations, as follows:

\section{Bye-law XI}

The President shall be elected annually from among the Fellows.

\section{Regulation XI}

(1) As soon as may be practicable after the first day of January in any year the Council shall hold a nomination meeting and shall ... nominate not less than one candidate and not more than three candidates....
(2) Between the first day of January in any year and the date which is four clear weeks after the nomination meeting of the Council, written nominations, accompanied in each case by the nominees' written consent to stand for election, may be lodged with the Registrar, provided that each such nomination is supported in writing by not less than twelve Members of the College who are not members of the Council.

(3) An election by ballot shall be held in accordance with the provisions of the Regulations. The nominating meeting of the Council will be held on 19 June 1992 and the last date for receiving nominations under (2) above will therefore be 17 July 1992. Professor A. C. P. Sims will retire from the office of President in July 1993 and is therefore ineligible for re-election. The newly elected President will take office during the Annual General Meeting in July 1993. 